\title{
Characterization of potato genotypes using molecular markers
}

\author{
Eliana Antonia Silveira Collares ${ }^{(1)}$, Eva Choer $^{(2)}$ and Arione da Silva Pereira ${ }^{(2)}$ \\ (1)Universidade Federal de Pelotas, Colegiado de Pós-graduação em Agronomia, Caixa Postal 354, CEP 96001-970 Pelotas, RS. (2)Embrapa \\ Clima Temperado, Caixa Postal 403, CEP 96001-970 Pelotas, RS. E-mail: arione@cpact.embrapa.br
}

\begin{abstract}
The objective of this work was to characterize 27 potato genotypes, using molecular markers. Polyacrylamide gel electrophoresis, RAPD techniques and isozymes of esterase, phosphoglucomutase and soluble proteins were analyzed in tubers, and isocitrate dehydrogenase, aspartate transaminase, phosphoglucomutase and peroxidase, in leaves. Eighteen primers were tested and four were chosen, kits OPX (01, 04 and 09) and OPY (07), to analyze RAPD markers in leaf extracts. Similarity and cluster analysis were conducted using Jaccard coefficient and the unweighted pair-group method using arithmetic average. Despite the differences detected in the analysis of proteins and isozymes in the tubers, as well as of isozymes in the leaves, the characterization of all genotypes through gel electrophoresis was not possible, while RAPD markers were efficient to characterize all the 27 genotypes.
\end{abstract}

Index terms: Solanum tuberosum, electrophoresis, isozymes, RAPD, genetic similarity.

\section{Caracterização de genótipos de batata por marcadores moleculares}

\begin{abstract}
Resumo - O objetivo deste trabalho foi caracterizar, por meio de marcadores moleculares, 27 genótipos de batata. Foram empregadas técnicas de eletroforese em gel de poliacrilamida e RAPD, e analisadas isoenzimas de esterase, fosfoglucomutase e proteína em tubérculos, isocitrato desidrogenase, aspartato transaminase, fosfoglucomutase e peroxidase, em folhas. Dos 18 primers testados, foram selecionados quatro dos kits OPX (01, 04 e 09) e OPY (07) para análise de RAPD em folhas. As análises de similaridade e de agrupamento entre os genótipos foram feitas empregando-se o coeficiente de Jaccard e o método da média aritmética não ponderada. Apesar das diferenças observadas nas análises de proteína e de isoenzimas, em tubérculos e em folhas, não foi possível a caracterização de todos os genótipos por esta técnica, enquanto os marcadores RAPD mostram-se eficientes em caracterizar as cultivares e clones de batata.
\end{abstract}

Termos para indexação: Solanum tuberosum, eletroforese, isoenzimas, RAPD, similaridade genética.

\section{Introduction}

Potato (Solanum tuberosum L.) is one of the most cultivated vegetable crops and it is highly consumed in that country. In 2001, 152,233 ha were grown in Brazil, being 37,070 ha in Rio Grande do Sul State, which harvested 384,501 t (Agrianual, 2003). Potato produces the highest yield of energy and proteins per hectare a day $\left(1.4 \mathrm{~kg}\right.$ protein ha- ${ }^{-1}$ day $\left.^{-1}\right)$, overcoming wheat $(1.3 \mathrm{~kg}$ protein ha ${ }^{-1}$ day $\left.^{-1}\right)$ and rice $\left(1.0 \mathrm{~kg}_{\text {protein }} \mathrm{ha}^{-1} \mathrm{day}^{-1}\right)$. Furthermore, it is a source of vitamins, mainly B and C complexes, and of mineral salts. Although it is included among high energetic value foods, it presents a low caloric value. It is also outstanding for medicinal purpose, such as gastrointestinal and hepatic infections (Silva, 1991).

The world's largest potato collection, in Peru, includes more than 5,000 accessions of cultivated and wild potatoes (Centro Internacional de la Papa, 2004), however, the world potatoes have a narrow genetic basis due to its development from a few genotypes originated in South America. After the late blight (Phytophthora infestans) epidemics of the 1940's in Europe, that genetic basis became still narrower, due to the lack of resistance of available cultivars (Salaman, 1954). This situation is of more concern in tropical and subtropical countries, whose breeding programs utilize European cultivars as genitors, generally very closely related (Buso, 1990). In Brazil, the potato crop is very dependent upon European cultivars, which are used in more than $70 \%$ of the cultivated area.

Genetic variability is essential for breeding and selection of superior genotypes (Clegg, 1990). The narrow genetic relationship among cultivars, as well as the difficulty to get true seeds from many cross combinations, suggest that it is necessary to cross 
genotypes that have genetic divergence. The selection of genitors and characterization of the existing genetic variability is decisive to improve efficiency of breeding programs (Barbosa Neto \& Bered, 1998). Therefore, the classification of genitors in heterotic groups and the crossing between distinct genetic types contribute to widen genetic variance (Messmer et al., 1993).

Several methodologies have been used to characterize and evaluate the similarity or genetic distance between genotypes; among them, the isozymes and DNA fragments are outstanding. Recent developments of molecular genetics resulted in several procedures based on DNA for detecting genetic polymorphism. RAPD technique is being used successfully to identify, characterize and estimate genetic divergence of potato cultivars (Moisan-Thiéry et al., 2001; Rocha et al., 2002).

The objective of this work was to characterize 19 cultivars and eight elite potato clones from the collection maintained by Embrapa Clima Temperado, by using isozyme and protein analysis and RAPD markers.

\section{Material and Methods}

Nineteen potato cultivars [Achat, Asterix, Atlantic, Baronesa, Baronesa pink spot (p.s.), Baronesa white (w.), BR-3, Canguçu, Cascata, Catucha, Cerrito Alegre, Cristal, Eliza, Elvira, Monte Bonito, Piratini, Santo Amor, Santa Silvana and Trapeira] and eight breeding clones (2AC-917-7-80, C-1226-35-80, C-1311-11-82, C-1485-2-87, C-1684-7-93, C-1730-7-94, C-1740-11-95 and CR-1208-98-80), growing in the field at Embrapa Clima Temperado, Pelotas $\left(31^{\circ} \mathrm{SL}\right)$, RS, were characterized. Leaf samples were collected from five plants per genotype, at blooming, and tuber samples were taken after harvest and kept for a month at room temperature before analysis.

Isozymes of peroxidase (PX), aspartate transaminase (AT), isocitrate dehydrogenase (IDH), phosphoglucomutase (PGM) were analyzed in leaves, and esterase (EST), phosphoglucomutase (PGM) and protein (PT) in tubers. From each sample, $10 \mathrm{mg}$ were squeezed directly (1:1) in gel buffer containing $0.15 \%$ of 2-mercaptoethanol. Horizontal electrophoresis of polyacrylamide gels, with 5\% (leaf IDH and PX, tuber PGM and PT) or 6\% (leaf AT and tuber EST), were used with buffer systems described by Shields et al. (1983) (leaf IDH, tuber PGM), and Scandalios (1969) (leaf PX and AT, tuber EST and PT). Staining methods were those referred to by Vallejos (1983) (IDH and PGM), Scandalios (1969) (PX) and Ayala et al. (1972) (AT). Protein was stained by a solution containing $60 \mathrm{mg}$ of comassie blue in $100 \mathrm{~mL}$ of water:methanol:acetic acid fixer (5:5:1).

Samples for RAPD (Random Amplified Polymorphic DNA) consisted of $120 \mathrm{mg}$ of young leaves collected from each genotype. Genomic DNA extractions and separation of amplified fragments by electrophoresis were based on the protocol described by Ferreira \& Grattapaglia (1998). DNA concentration was determined after electrophoresis in $1 \%$ agarose gel, comparing to known amounts of HindIII-digested bacteriophage $\lambda$ DNA and establishing a final concentration of $5 \mathrm{ng} \mu \mathrm{L}^{-1}$.

Amplification reactions followed a modified Ferreira \& Grattapaglia (1998) method. Reactions were performed in a total volume of $13 \mu \mathrm{L}$, containing $3.64 \mu \mathrm{L}$ of autoclaved pure water, $1.3 \mu \mathrm{L}$ of $10 \mathrm{x}$ Tris- $\mathrm{HCl}$ buffer, $0.78 \mu \mathrm{L}$ of $\mathrm{MgCl}_{2}(50 \mathrm{mM}), 1.04 \mu \mathrm{L}$ of each dNTPs (2.5 mM), $1.4 \mu \mathrm{L}$ of purified BSA $\left(5.0 \mathrm{mg} \mathrm{mL}^{-1}\right), 3.0 \mu \mathrm{L}$ of primer $\left(5 \mathrm{ng} \mu \mathrm{L}^{-1}\right), 0.2 \mu \mathrm{L}$ of Taq DNA polymerase ( 5 units $\mu \mathrm{L}^{-1}$ ) and $2.0 \mu \mathrm{L}$ of genomic DNA $\left(5.0 \mathrm{ng} \mu \mathrm{L}^{-1}\right.$ ). Each reaction was overlaid with a drop of mineral oil. DNA amplification was carried out in a thermal cycler (RoboCycler 96 Temperature Cycler-Stratagene) programmed for 40 repeated cycles on the following conditions: $1 \mathrm{~min}$ at $92^{\circ} \mathrm{C}$ (denaturation), $1 \mathrm{~min}$ at $35^{\circ} \mathrm{C}$ (annealing), $2 \mathrm{~min}$ at $72^{\circ} \mathrm{C}$ (extension) and a final step of 5 min at $72^{\circ} \mathrm{C}$.

The RAPD products were separated by horizontal electrophoresis using 1.2\% agarose gels in Tris-borate buffer at $5 \mathrm{~V} \mathrm{~cm}^{-1}$ for three hours and visualized by ethidium bromide staining $(5.0 \mu \mathrm{L}$ of a solution of $10 \mathrm{mg} \mathrm{mL}^{-1}$ for gel of $100 \mathrm{~mL}$ ), left to migrate for $8 \mathrm{~cm}$. Gels were photographed under ultraviolet light $(302 \mathrm{~nm})$ using a Polaroid camera, 667 print and a Photo Print image visualizer. For all gels, a white proof was used in a standard DNA ladder of $1 \mathrm{~Kb}(4 \mu \mathrm{L}$, in a marker extraction buffer ratio of 1:1), with known fragment sizes.

A total of 18 primers were used for screening: fourteen of OPX and OPY kits from the Operon Technologies and four oligonucleotide sequences $(105,73,195$ and 197) from the University of British Columbia, Vancouver, Canada. Similarity and grouping analysis among genotypes were calculated using NTSYS statistical analysis package (Rohlf, 1989) and applying Jaccard 
coefficient and the unweighted pair-group method arithmetic averages (UPGMA); resulting clusters were expressed as dendrogram. Graphs were sectioned at precision level of 0.75 , so that formed groups could be observed.

\section{Results and Discussion}

The broadest isozyme variability in tubers, 30 days after harvesting, was observed for esterase, which showed 13 electrophoretic patterns, with three to seven bands per pattern (Table 1). Iglesias \& Lozoya-Saldaña (1996), analyzing esterase activity in 25 potato cultivars, identified 22 genotypes. Rocha et al. (2002) also found a high polymorphism degree for esterase. According to Desborough \& Peloquin (1967), isozymes of esterase in tubers are reliable and valuable biochemical markers.
Six and three isozymes of phosphoglucomutase were observed in tubers and leaves of potatoes, which were distributed into six and two patterns, respectively (Tables 1 and 2). Desborough (1983) reported that three different forms of phosphoglucomutase were found in potatoes. Suurs et al. (1989) observed in Solanum and Lycopersicon species from two to five molecular forms of phosphoglucomutase. Genotypes showed 11 protein sites of activity in tubers, distributed in eight patterns (Table 1). Desborough \& Peloquin $(1966,1967,1968)$ used protein patterns to differentiate Solanum tuberosum from other Solanum species.

Only three electrophoretic patterns of isocitrate dehydrogenase were observed in leaves, varying from two to three bands per pattern (Table 2). Waara et al. (1989) observed the same variation in band number, in leaves of potato somatic hybrids and potato parents.

Table 1. Electrophoretic patterns of esterase (EST), protein (PT) and phosphoglucomutase (PGM) in tubers of potato cultivars and clones.

\begin{tabular}{|c|c|c|}
\hline $\begin{array}{l}\text { Enzyme/ } \\
\text { pattern }\end{array}$ & Relative mobility & Genotype \\
\hline EST/A & $0.93 ; 1.00 ; 1.03 ; 1.06 ; 1.09$ & $\begin{array}{l}\text { Piratini, Santa Silvana, Baronesa p.s., Baronesa w., Baronesa, Achat, Catucha, 2AC- } \\
\text { 917-7-80, C-1226-35-80, CR-1208-98-80, C-1730-7-94, C-1684-7-93 }\end{array}$ \\
\hline EST/B & $0.93 ; 0.96 ; 1.00 ; 1.03 ; 1.09$ & Atlantic, C-1740-11-95 \\
\hline $\mathrm{EST} / \mathrm{C}$ & $0.96 ; 1.00 ; 1.03 ; 1.09 ; 1.12$ & Cristal, Santo Amor, Cascata \\
\hline EST/D & $0.93 ; 0.96 ; 1.00 ; 1.09$ & Elvira \\
\hline $\mathrm{EST} / \mathrm{F}$ & $0.96 ; 1.00 ; 1.04 ; 1.09$ & Canguçu \\
\hline EST/G & $0.98 ; 1.04 ; 1.09$ & Eliza \\
\hline $\mathrm{EST} / \mathrm{H}$ & $1.00 ; 1.03 ; 1.06 ; 1.09$ & Trapeira \\
\hline EST/I & $0.92 ; 1.00 ; 1.03 ; 1.09 ; 1.12$ & Cerrito Alegre \\
\hline $\mathrm{EST} / \mathrm{J}$ & $0.93 ; 1.00 ; 1.04$ & Monte Bonito \\
\hline $\mathrm{EST} / \mathrm{K}$ & $0.93 ; 0.96 ; 1.00 ; 1.03 ; 1.06 ; 1.09 ; 1.12$ & C-1313-11-82, C-1485-2-87, C-1485-6-87 \\
\hline $\mathrm{EST} / \mathrm{L}$ & $0.96 ; 1.00 ; 1.03 ; 1.06 ; 1.09 ; 1.12$ & Asterix \\
\hline EST/M & $0.93 ; 1.00 ; 1.09 ; 1.12$ & BR-3 \\
\hline $\mathrm{EST} / \mathrm{N}$ & $1.00 ; 1.03 ; 1.09 ; 1.14$ & C-1750-15-95 \\
\hline $\mathrm{PT} / \mathrm{A}$ & $0.90 ; 1.00 ; 1.02 ; 1.08$ & Atlantic, C-1208-98-80 \\
\hline $\mathrm{PT} / \mathrm{B}$ & $1.00 ; 1.08 ; 1.10 ; 1.12$ & Cristal \\
\hline $\mathrm{PT} / \mathrm{C}$ & $1.06 ; 1.08 ; 1.12$ & Santo Amor, Monte Bonito \\
\hline $\mathrm{PT} / \mathrm{D}$ & $1.00 ; 1.02 ; 1.06 ; 1.08$ & $\begin{array}{l}\text { Piratini, Elvira, Santa Silvana, Baronesa p.s., Baronesa w., Trapeira, Baronesa, Achat, } \\
\text { Catucha, Cerrito Alegre, Cascata, Canguçu, Asterix, BR-3, 2AC-917-7-80, C-1226-35 } \\
\text { 80, C-1740-11-95, C-1684-7-93 }\end{array}$ \\
\hline $\mathrm{PT} / \mathrm{E}$ & $1.00 ; 1.03 ; 1.08 ; 1.12$ & C-1311-11-82, C-1750-15-95 \\
\hline $\mathrm{PT} / \mathrm{F}$ & $1.04 ; 1.06 ; 1.10 ; 1.14$ & Eliza \\
\hline $\mathrm{PT} / \mathrm{G}$ & $1.00 ; 1.03 ; 1.06 ; 1.08 ; 1.13$ & C-1485-2-87, C-1485-6-87 \\
\hline $\mathrm{PT} / \mathrm{H}$ & $1.08 ; 1.10 ; 1.14$ & C-1730-7-94 \\
\hline $\mathrm{PGM} / \mathrm{A}$ & $0.75 ; 0.87 ; 1.00 ; 1.22 ; 1.32$ & Baronesa p.s., Baronesa w., Baronesa, Trapeira, Cascata, Canguçu, C-1311-11-82, \\
\hline $\mathrm{PGM} / \mathrm{B}$ & $0.75 ; 0.87 ; 1.00 ; 1.32 ; 1.38$ & C-1750-15-95 \\
\hline $\mathrm{PGM} / \mathrm{C}$ & $0.75 ; 0.87 ; 1.00 ; 1.22 ; 1.38$ & $\begin{array}{l}\text { Atlantic, C-1208-98-80, C-1740-11-95 } \\
\text { Cristal, Cerrito Alegre, Eliza }\end{array}$ \\
\hline $\mathrm{PGM} / \mathrm{E}$ & $0.87 ; 1.00 ; 1.22 ; 1.32$ & $\begin{array}{l}\text { Piratini, Elvira, Monte Bonito, Achat, Catucha, Asterix, BR-3, 2AC-917-7-80, } \\
\text { C-1485-2 87, C-1485-6-87, C-1226-35-80, C-1730-7-94 }\end{array}$ \\
\hline PGM/I & $0.87 ; 1.00 ; 1.22 ; 1.38$ & Santo Amor \\
\hline $\mathrm{PGM} / \mathrm{J}$ & $0.75 ; 0.87 ; 1.00 ; 1.22 ; 1.32 ; 1.38$ & Santa Silvana \\
\hline
\end{tabular}


Douches \& Ludlam (1991) used this isozyme system as well as nine others in the study of phylogenetic relationships of ten North American potato cultivars.

Four anodic bands of aspartate transaminase were observed in leaves, which allowed to distinguish four patterns (Table 2). According to Gottlieb (1982), generally three to four isozymes of aspartate transaminase are identified.

The leaves showed more polymorphism in peroxidase zymograms than the other enzymes, presenting seven anodic bands, resulting in five patterns (Table 2). Iglesias et al. (1995) reported the presence of biochemical polymorphism as well as better resolution and repeatability in peroxidase of leaf tissue than that observed in shoot and root samples.

The similarity coefficients based on the presence or absence of isozymes and of proteins in tubers varied from 0.22 in comparisons of cultivar Eliza with other clones C-1311-11-82, C-1485-2-87 and C-14856-87, and 1.00, when compared to cultivars Baronesa p.s. and Baronesa w. and Baronesa; Piratini and Catucha and clones 2AC-917-7-80, C-1226-35-80 and C1684-7-93 compared to clone C-1485-2-87 and C-1485-6-87.

The analysis of the phenogram shows the formation of two main groups (Figure 1). The first one was formed only by the cultivar Eliza and the second cut to the precision level of 0.75 , subdivided in 12 subgroups, each one made of 11 accesses. On the basis of isoenzymes in leaves, the genotypes Atlantic and C-1740-11-95 showed the smallest similarity (0.50) and Elvira, Catucha and 2AC-917-7-80; Monte Bonito and C-1750-15-95; Baronesa p.s., Baronesa w. and Baronesa; Eliza and C-1311-11-82; C-1484-2-87 and C-1485-6-87; Atlantic and CR-1208-98-80 had the highest similarity (1.00) (Figure 1). Rocha et al. (2002) did not find dissimilarity between cultivars Elvira and Santo Amor. However, the similarity observed in this study between them was 0.81 . Two main groups were formed: one formed only by cultivar Achat and the other formed by five subgroups. In this last one, the number of genotypes per subgroup varied from one to 23 , indicating that the variability in isozymes and proteins in tubers was higher than that in leaves.

Table 2. Electrophoretic patterns of phosphoglucomutase (PGM), isocitrate dehydrogenase (IDH), aspartate transaminase (AT) and peroxidase (PX), in leaves of potato cultivars and clones.

\begin{tabular}{|c|c|c|}
\hline $\begin{array}{l}\text { Enzyme/ } \\
\text { pattern }\end{array}$ & Relative mobility & Genotype \\
\hline $\mathrm{PGM} / \mathrm{G}$ & $0.75 ; 0.87 ; 1.00$ & $\begin{array}{l}\text { Santa Silvana, Baronesa p.s., Baronesa w., Trapeira, Baronesa, Cristal, Atlantic, Cerrito } \\
\text { Alegre, Cascata, Eliza, Canguçu, C-1311-11-82, CR-1208-98-80, C-1740-11-95, } \\
\text { C-1750-15-95 }\end{array}$ \\
\hline $\mathrm{PGM} / \mathrm{H}$ & $0.87 ; 1.00$ & $\begin{array}{l}\text { Piratini, Elvira, Monte Bonito, Achat, Santo Amor, Catucha, Asterix, BR-3, } \\
\text { 2AC-917-7-80, C-1485-2-87, C-1226-35-80, C-1485-6-87, C-1730-7-94, C-1684-7-93 }\end{array}$ \\
\hline IDH/A & $1.00 ; 1.07 ; 1.13$ & $\begin{array}{l}\text { Santa Silvana, Monte Bonito, Trapeira, Santo Amor, Cerrito Alegre, C-1485-2-87, } \\
\text { C-1485-6-87, C-1750-15-95, C-1730-7-94 }\end{array}$ \\
\hline IDH/B & $1.00 ; 1.07$ & $\begin{array}{l}\text { Piratini, Elvira, Baronesa p.s., Baronesa w., Baronesa, Cristal, Achat, Atlantic, } \\
\text { Catucha, Cascata, Eliza, Canguçu, BR-3, C-1311-11-82, 2AC-917-7-80, C-1226-35-80, } \\
\text { CR-1208-98-80, C-1684-7-93 }\end{array}$ \\
\hline IDH/D & $1.07 ; 1.13$ & Asterix, C-1740-11-95 \\
\hline $\mathrm{AT} / \mathrm{A}$ & $0.53 ; 1.00 ; 1.03$ & $\begin{array}{l}\text { Elvira, Monte Bonito, Trapeira, Achat, Santo Amor, Atlantic, Catucha, Cerrito } \\
\text { Alegre, Eliza, Asterix, BR-3, C-1311-11-82, 2AC-917-7-80, C-1226-35-80, } \\
\text { CR-1208-98-80, C-1750-15-95, C-1730-7-94, C-1684-7-93 }\end{array}$ \\
\hline $\mathrm{AT} / \mathrm{C}$ & $1.00 ; 1.03$ & $\begin{array}{l}\text { Piratini, Santa Silvana, Baronesa p.s., Baronesa w., Baronesa, Canguçu, C-1485-2-87, } \\
\text { C-1485-6-87 }\end{array}$ \\
\hline $\mathrm{AT} / \mathrm{D}$ & $0.53 ; 0.62 ; 1.03$ & Cristal \\
\hline $\mathrm{AT} / \mathrm{E}$ & $0.53 ; 1.03$ & Cascata, C-1740-11-95 \\
\hline $\mathrm{PX} / \mathrm{B}$ & $0.85 ; 0.94 ; 1.00 ; 1.04 ; 1.07 ; 1.14 ; 1.18$ & $\begin{array}{l}\text { Elvira, Santo Amor, Atlantic, Catucha, Asterix, 2AC-917-7-80, CR-1208-98-80, } \\
\text { C-1740-11-95 }\end{array}$ \\
\hline $\mathrm{PX} / \mathrm{C}$ & $1.00 ; 1.04 ; 1.07 ; 1.14 ; 1.18$ & Baronesa p.s., Baronesa w., Trapeira, Baronesa, Cristal, BR-3 \\
\hline $\mathrm{PX} / \mathrm{F}$ & $1.00 ; 1.14 ; 1.18$ & Achat \\
\hline $\mathrm{PX} / \mathrm{G}$ & $1.00 ; 1.07 ; 1.14 ; 1.18$ & Santa Silvana, Cerrito Alegre \\
\hline $\mathrm{PX} / \mathrm{H}$ & $0.94 ; 1.00 ; 1.04 ; 1.07 ; 1.14 ; 1.18$ & $\begin{array}{l}\text { Piratini, Monte Bonito, Cascata, Eliza, Canguçu, C-1311-11-82, C-1485-2-87, } \\
\text { C-1485-6-87, C-1226-35-80, C-1750-15-95, C-1730-7-94, C-1684-7-93 }\end{array}$ \\
\hline
\end{tabular}




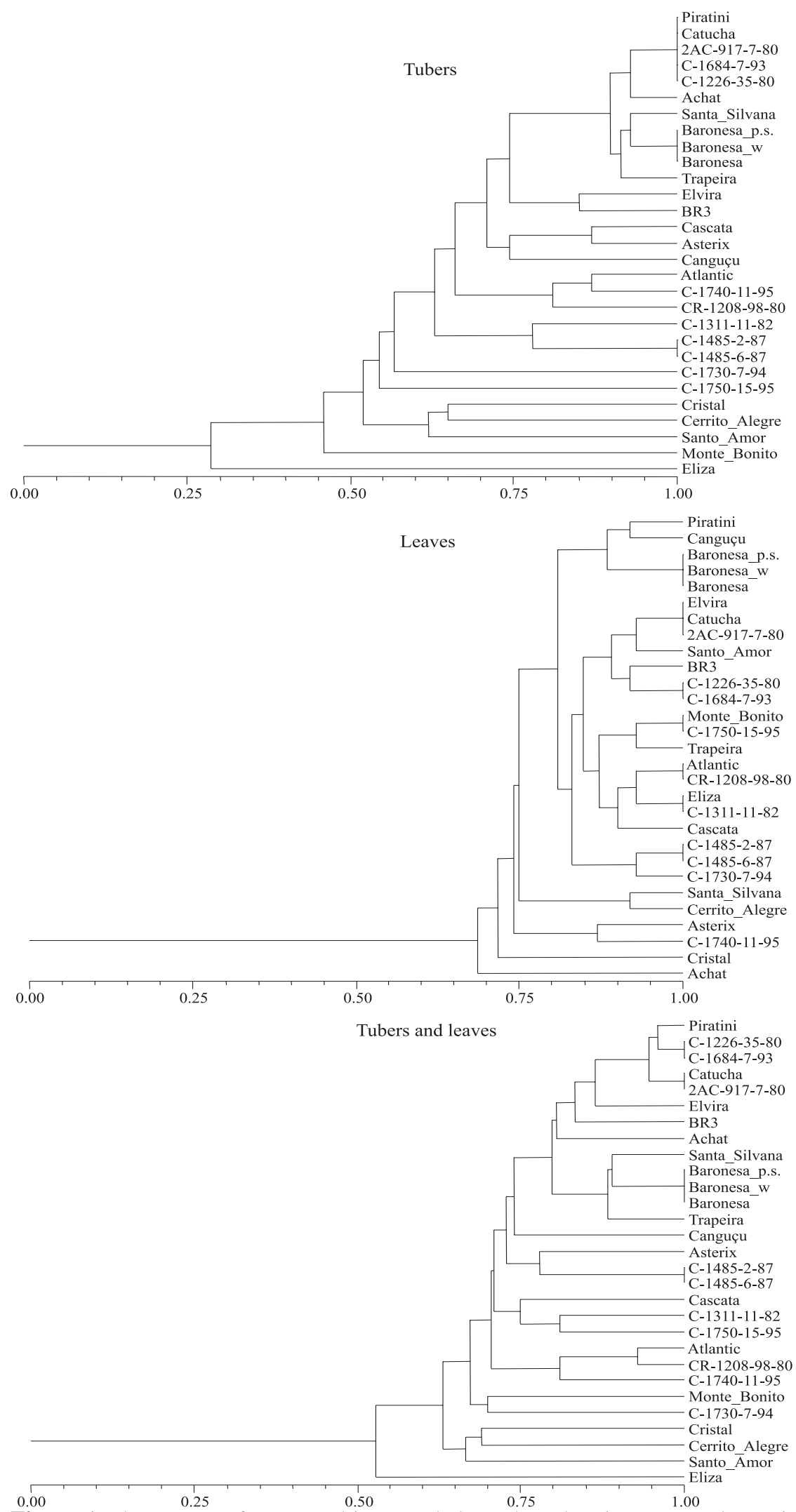

Figure 1. Phenogram of potato cultivars and clones based on isozyme and protein analysis in tubers and isozymes in leaves.

Pesq. agropec. bras., Brasília, v.39, n.9, p.871-878, set. 2004 
By the joint analysis of proteins and isozymes in tubers and isozymes in leaves, the smallest similarity $(0.45)$ was shown by Eliza and C-1485-2-87 genotypes and the highest (1.00) by Catucha and 2AC-917-7-80; C-1226-35-80 and C-1684-7-93; Baronesa, Baronesa p.s. and Baronesa w.; C-1485-2-87 and C-1485-6-87. The genotypes were also organized in two groups (Figure 1). Eliza formed one group and the other ten subgroups, varying from one to 13 accesses per subgroup, formed another group. Data of electrophoretic analysis of tubers and leaves permitted to separate the 27 genotypes analyzed. Similarly, Augustin \& Costa (1992), when characterizing 12 potato cultivars with isozymes, used leaves and tubers and did not differentiate three genotypes (Baronesa, Cerrito Alegre and Santa Silvana). Rocha et al. (2002), using isozymes and protein analysis in tubers, separated nine genotypes of Solanum tuberosum L., in eight groups, and only one of them was formed by two cultivars (Baronesa and Macaca). Douches \& Ludlam (1991) were able to separate 112 potato cultivars in 95 groups, however, they used 13 isozyme systems, including some used in this work. Moore \& Durham (1992) reported that the main difficulty in using isozymes for identifying the genotypes consists of the possibility of the lack of enough enzyme polymorphism for cultivar identification. This may be attributed to the inherent lack of polymorphism, the nature of species, the lack of genetic variability in the studied cultivars or the small number of analyzed loci.

In the RAPD marker analysis, the selected primers OPX1, OPX4, OPX9 and OPY7, generated 43 amplified products, with fragment numbers varying from five (OPX-4) to 14 (OPX-9), averaging 10.75 bands per prime (Table 3 ), out of which 39 (90\%) were polymorphic and four (10\%) were monomorphic. By means of the four RAPD markers, all genotypes were identified and separated. Forapani et al. (1999) and Moisan-Thiéry et al. (2001), using only three primers, identified,

Table 3. Monomorphic and polymorphic bands in potato genotypes generated by amplification using RAPD technique ${ }^{(1)}$.

\begin{tabular}{lcccr}
\hline Primer & $\begin{array}{c}\text { Sequency } \\
\left(5^{\prime} \rightarrow 3^{\prime}\right)\end{array}$ & $\begin{array}{c}\text { Polymorphic } \\
\text { bands }\end{array}$ & $\begin{array}{c}\text { Monomorphic } \\
\text { bands }\end{array}$ & Total \\
\hline OPX 01 & CTGGGCACGA & 10 & 0 & 10 \\
OPX 04 & CCGCTACCGA & 5 & 0 & 5 \\
OPX 09 & GGTCTGGTTG & 14 & 0 & 14 \\
OPY 07 & AGAGCCGTCA & 10 & 4 & 14 \\
\hline
\end{tabular}

${ }^{(1)}$ RAPD: Random amplified polymorphic DNA. respectively, 37 and 57 potato genotypes. Demeke et al. (1993), using the RAPD technique, with only two primers, identified 36 commercial potato cultivars. According to these authors, specific primers seem to produce more fragments and more DNA amplified polymorphisms, and are, therefore, adequate for identifying potato cultivars by the RAPD technique. Ghislain et al. (1999), using 12 primers, obtained 102 polymorphic markers, in the discrimination of 128 accesses of andigena potato.

The OPX-09 primer resulted in the highest number of polymorphic bands, providing the formation of the largest number of patterns (25), and, consequently the best genotype separation (Figure 2). Rocha et al. (2002) also observed that OPX-09 was the most polymorphic, and separated all nine potato genotypes studied.

The similarity analysis based on RAPD markers showed that clones C-1226-35-80 and C-1485-6-87 presented the least similarity (0.15) while Trapeira and Canguçu had the greatest similarity (0.86). These data revealed broad variability among the genotypes. Isenegger et al. (2001) found similarity values from 0.67 to 0.9 among potato cultivars. The grouping analysis allowed the separation of genotypes in two main groups; one containing only the cultivar Piratini and the other, cut to precision level of 0.75 , formed by 18 subgroups. Each one contained from one to three genotypes (Figure 3).

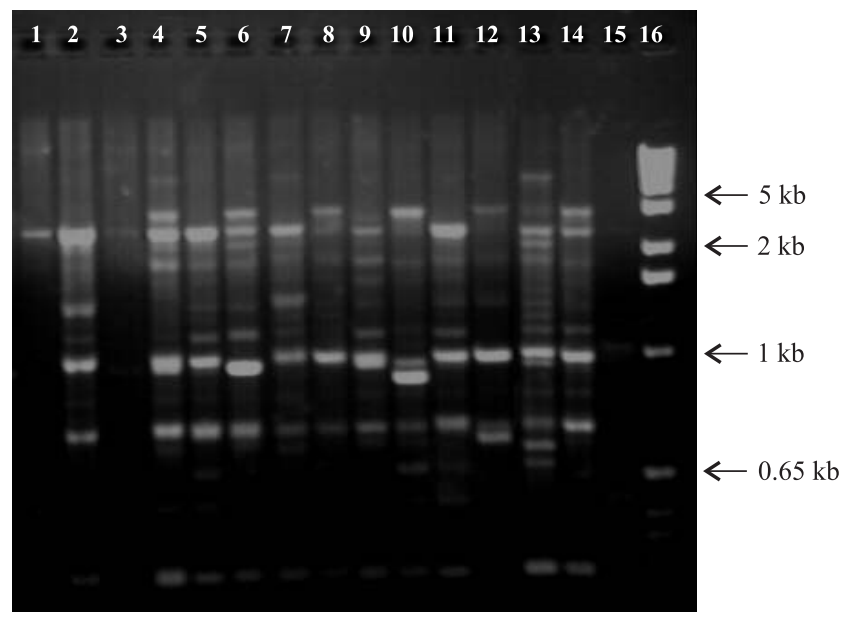

Figure 2. Amplified products using the primer OPX-09 on $5 \mathrm{ng}$ genomic DNA of potato genotypes Santo Amor (1), BR-3 (2), C-1720-40-94 (3), Monalisa (4), Cerrito Alegre (5), C-1485-6-87 (6), C-1311-11-82 (7), C-1750-15-95 (8), 2-CRI-1149-1-78 (9), Macaca (10), C-1208-98-80 (11), C-1485-16-87 (12), Baronesa (13), Elvira (14), White proof (15), $1 \mathrm{~kb}$ ladder molecular marker (16). 


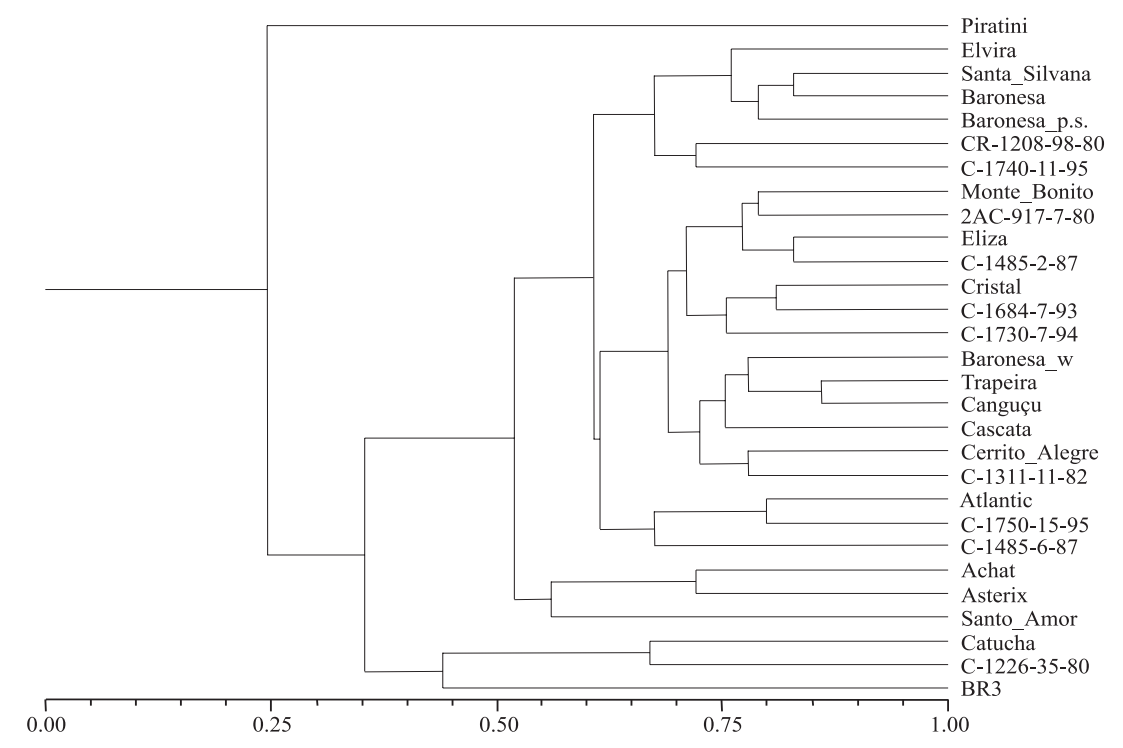

Figure 3. Phenogram of potato cultivars and clones based on RAPD (Random amplified polymorphic DNA) marker analysis.

Although some genotypes present close genetic relationship (C-1485-2-87 and C-1485-6-87, Trapeira and Santa Silvana, Cerrito Alegre and Cascata, sibs; Canguçu andPiratini, Eliza and C-1311-11-82, Santo Amor and Cerrito Alegre, Santo Amor and Cascata, C-1740-11-95 and C1750-15-95, half sibs), they showed not so high similarity coefficients $(0.48,0.60,0.67,0.25,0.68,0.50,0.56$ and 0.50 , respectively). In some cases, the values were smaller than those detected among non-related genotypes. Similarly, Demeke et al. (1996) observed that some cultivars closely related might often be so different as those with no immediate affinity. According to these authors, this observation can explain the poor correlation among coancestries and on performance of the progeny. Hosaka et al. (1994), studying the genetic relation of 73 Japanese potato cultivars, reported that the patterns of RAPD banding of closely related cultivars were grouped and they concluded that these patterns reflected the pedigree affinity.

Ford \& Taylor (1997) were able, by means of this technique, to differentiate potato cultivars closely related, which was not possible by morphological techniques. Forapani et al. (1999), Polzerova \& Ptacek (2000), Isenegger et al. (2001) and Moisan-Thiéry et al. (2001) considered RAPD markers a useful tool for characterizing and identifying cultivars and for differentiating and estimating genetic relationship, besides to be a fast technique.

Results demonstrated that it is possible to distinguish potatoes cultivars and clones using the RAPD technique, which provides a better evaluation of genetic divergence as compared to isozyme and protein analysis. Similarly,
Park et al. (1996) concluded that the RAPD technique was more effective for identifying potato cultivars and breeding lines than protein and isozyme technique.

\section{Conclusions}

1. The RAPD technique is efficient to characterize potato cultivars and clones.

2. Protein and isozyme analyses in tubers and in leaves are not efficient to characterize potato cultivars and clones, but can be used as an auxiliary method.

\section{References}

AGRIANUAL 2003: Anuario da agricultura brasileira, São Paulo: FNP Consultoria, 2003. 544p.

AUGUSTIN, E.; COSTA, D.M. Caracterização de cultivares de batata através de isoenzimas. Horticultura Brasileira, v.10, p.3-5, 1992.

AYALA, F.J.; POWELL, J.R.; TRACEY, M.L.; MOURÃO, C.A.; PÉREZ-SALAS, S. Enzyme variability in the Drosophila willistoni group. IV. Genic variation in natural populations of Drosophila willistoni. Genetics, v.70, p.113-139, 1972.

BARBOSA NETO, J.F.; BERED, F. Marcadores moleculares e diversidade genética no melhoramento de plantas. In: MILACK, S. (Ed.). Marcadores moleculares em plantas. Porto Alegre: UFRGS, 1998. p.29-41.

BUSO, J.A. Os programas de melhoramento genético da batata no Brasil. In: HIDALGO, O.A.; RINCÓN, H.R. (Ed.). Avances en el mejoramiento genético de la papa en los países del Cono Sur. Lima: Centro Internacional de la Papa, 1990. p.31-34.

CENTRO INTERNACIONAL DE LA PAPA (Lima, Peru). About potatoes. Disponível em <http://www.cipotato.org/potato/ potato.htm>. Acesso em: 26 mar. 2004. 
CLEGG, M.T. Molecular diversity in plant populations. In: BROWN, A.H.D.; CLEGG, M.T.; KAHLER, A.L.; WEIR, B.S. (Ed.). Plant population genetics, breeding, and genetic resources. Sunderland: Sinauer Associates Inc., 1990. p.98-115.

DEMEKE, T.; KAWCHUC, L.M.; LYNCH, D.R. Identification of potato cultivars and clonal variants by random amplified polymorphic DNA analysis. American Potato Journal, v.70, p.561-570, 1993.

DEMEKE, T.; LYNCH, D.R.; KAWCHUK, L.M.; KOZUB, G.C.; ARMSTRONG, J.D. Genetic diversity of potato determined by random amplified polymorphic DNA analysis. Plant Cell Reports, v.15, p.662-667, 1996.

DESBOROUGH, S. Potato (Solanum tuberosum L.). In: TANKSLEY, S.D.; ORTON, T.J. (Ed.). Isozymes in plant genetics and breeding. Amsterdam: Elsevier, 1983. Part. B, p.167-188.

DESBOROUGH, S.; PELOQUIN, S.J. Disc electrophoresis of tuber proteins from Solanum species and interspecific hybrids. Phytochemistry, v.5, p.727-734, 1966.

DESBOROUGH, S.; PELOQUIN, S.J. Esterase isozymes from Solanum tubers. Phytochemistry, v.6, p.989-994, 1967.

DESBOROUGH, S.; PELOQUIN, S.J. Potato variety identification by use of electrophoretic patterns of tuber proteins and enzymes. American Potato Journal, v.45, p.220-229, 1968.

DOUCHES, D.S.; LUDLAM, K. Electrophoretic characterization of North American potato cultivars. American Potato Journal, v.68, p.767-780, 1991.

FERREIRA, M.E.; GRATTAPAGLIA, D. Introdução ao uso de marcadores moleculares em análise genética. 3.ed. Brasília: Embrapa-Cenargen, 1998. 220p.

FORAPANI, S.; CARBONI, A.; CASTELLANI, E.; MONDOLINO, G.; RANALLI, P. RAPD markers for potato germplasm characterization. Journal of Genetics and Breeding, v.53, p.143-147, 1999.

GHISLAIN, M.; ZHANG, D.; FAJARDO, D.; HUAMAN, Z.; HIJMANS, R.J. Marker-assisted sampling of the cultivated Andean potato Solanum phureja collection using RAPD markers. Genetic Resources and Crop Evolution, v.46, p.547-555, 1999.

GOTTLIEB, L.D. Conservation and duplication of isozymes in plants. Science, v.216, p.373-380, 1982.

HOSAKA, K.; MORI, M.; OGAWA, K. Genetic relationships of Japanese potato cultivars assessed by RAPD analysis. American Potato Journal, v.71, p.535-546, 1994.

IGLESIAS, L.; ESTÉVEZ, A.; COSTA, E.; RODRÍGUEZ, I. Variación en la composición de isoenzimas peroxidasas en papa (Solanum tuberosum L.). Cultivos Tropicales, v.16, p.51-53, 1995.

IGLESIAS, L.; LOZOYA-SALDAÑA, H. Esterase polymorphic activity establishes phylogenetic relationship among potato cultivars. Agrociencia, v.30, p.577-580, 1996.

ISENEGGER, D.A.; TAYLOR, P.W.J.; FORD, R.; FRANZ, P.; McGREGOR, G.R.; HUTCHINSON, J.F. DNA fingerprint and genetic relationships of potato cultivars (Solanum tuberosum L.) commercially grown in Australia. Australian Journal of Agricultural Research, v.52, p.911-918, 2001.
MESSMER, M.M.; MELCHINGER, A.E.; HERMANN, R.G.; BOPPENMAIER, J. Relationships among early european maize inbreds - II: comparison of pedigree and RFLP data. CropScience, v.33, p.944-950, 1993.

MOISAN-THIÉRY, M.; HINGRAT, Y.L.; KERLAN, M.C. Potato cultivars identification using molecular markers. Acta Horticulturae, v.546, p.471-477, 2001.

MOORE, G.A.; DURHAM, R.E. Molecular markers. In: HAMMERSCHLAG, F.A.; LITZ, R.E. (Ed.). Biotechnology of perennial fruit crops. Cambridge: Cambridge University Press, 1992. p.105-139.

PARK, Y.E.; KIM, K.S.; CHUNG, S.R.; YOO, Y.S.; SINS, Y.N.; LIM, H. Identification and genetic relationship of potato (Solanum tuberosum L.) cultivars and breeding lines via protein, isozyme and RAPD analysis. Journal of the Korean Society for Horticulture Science, v.37, p.386-391, 1996.

POLZEROVA, H.; PTACEK, J. Detection of DNA polymorphism in potato cultivar using RAPD technique. Czech Journal of Genetics and Plant Breeding, v.36, p.11-15, 2000.

ROCHA, B.H.G.; AUGUSTIN, E.; PEREIRA, A. da S.; FORTES, G.R. de L.; PETERS, J.A. Caracterização de cultivares de batata através de marcadores moleculares. Revista Científica Rural, v.7, p.42-51, 2002.

ROHLF, F.J. NTSYS-pc numerical taxonomy and multivariate analysis system. Version 1.5. New York: Exeter Software, 1989. 236p.

SALAMAN, R.N. The origin of the early European potato. Journal of the Linnean Society of London Botany, v.55, p.185-190, 1954.

SCANDALIOS, J.G. Genetic control of multiple molecular forms of enzymes in plants: a review. Biochemical Genetics, v.3, p.37-39, 1969.

SHIELDS, C.R.; ORTON, T.J.; STUBBER, C.W. An outline of general resource needs and procedures for the electrophoretic separation of active enzymes from plant tissue. In: TANKSLEY, S.D.; ORTON, T.J. (Ed.). Isozymes in plant genetics and breeding. Amsterdam: Elsevier, 1983. Part. A, p.443-468.

SILVA, A.C.F. da. Batata: alguns aspectos importantes. Agropecuária Catarinense, v.4, p.38-41, 1991.

SUURS, L.C.J.M.; JONGEDIJK, E.; TAN, M.M.C. Polyacrylamide gradiente-gel electrophoresis: a routine method for high resolution isozyme electrophoresis of Solanum and Lycopersicon species. Euphytica, v.40, p.181-186, 1989.

TAYLOR, P.W.J.; FORD, R. The application of RAPD markers for potato cultivar identification. Australian Journal of Agricultural Research, v.48, p.1213-1217, 1997.

VALLEJOS, C.E. Enzyme activity staining: In: TANKSLEY, S.D.; ORTON, T.J. (Ed.). Isozymes in plant genetics and breeding. Amsterdam: Elsevier, 1983. Part A, p.469-516.

WAARA, S.; TEGELSTRÖM, H.; WALLIN, A.; ERIKSSON, T. Somatic hybridization between anther derived dihaploid clones of potato (Solanum tuberosum L.) and the identification of hybrid plant by isozyme analysis. Theoretical and Applied Genetics, v.77, p.49-56, 1989.

Received on September 23, 2003 and accepted on April 26, 2004

Pesq. agropec. bras., Brasília, v.39, n.9, p.871-878, set. 2004 